九州大学学術情報リポジトリ

Kyushu University Institutional Repository

\title{
FOUR NEW SPECIES OF THE FORMOSAN SETENIS (COLEOPTERA, TENEBRIONIDAE)
}

Chujo, Michitaka

https://doi.org/10.5109/2416

出版情報: ESAKIA. 17, pp. 131-140，1981-11-30. Entomological Laboratory， Faculty of Agriculture, Kyushu University バージョン :

権利関係 : 


\title{
FOUR NEW SPECIES OF THE FORMOSAN SETENIS (COLEOPTERA, TENEBRIONIDAE)*
}

\author{
M ichitaka CHûjô \\ Hikosan Biological Laboratory, Faculty of Agriculture, \\ Kyushu University, Hikosan, Fukuoka 824-07, Japan
}

\begin{abstract}
Four new species, Setenis aritai, S. nitidula, S. similis and S. subvalgipes are described from Formosa. Three specimens from Formosa identified as S. striatipennis Lewis in my previous work (Kontyû 35(4): 378, 1967) are regarded as S. nitidula sp. nov.
\end{abstract}

\section{Setenis aritai sp. nov.}

Male. Elongate, gently convex, shining black.

Head comparatively flat, sparsely, strongly punctate ; frons slightly convex, front margin gently and roundly bent downwards, middle half very shallowly sinuate, clypeal suture rather vestigial; preocular area convex, shallowly intrudes into eye, inner ocular furrow continued to preocular area, inner ocular area very feebly convex. Eye large, strongly expanded outwards.

Antenna rather stout, nearly reaching middle part of pronotum, terminal 6 segments compressed, forming loose club, relative length of each segment (base to apex) $8: 4: 9: 6: 6: 6: 6: 6: 5: 5: 9$. Maxillary palpus nearly securiformed, apex weakly rounded. Mentum with dense, thick, erect, long hairs. Gular suture fine, visible, strongly carved from tempora to gula.

Pronotum rather transverse (ca. 8 : 9), gently, roundly convex, strongly, sparsely punctate; wholly, narrowly marginate except for middle half of front margin ; median groove comparatively deep, widest at middle part, disappearing for- and backwards; subbasal grooves short, transverse, sometimes disappeared; front margin nearly straight, front corner obtusely angulate; side margin roundly expanded outwards, sometimes undulate or angulate at middle part; hind corner rather acutely angulate, hind margin gradually expanded towards median part. Propleuron wide, very smooth. Prosternum roughly,

\footnotetext{
* Contribution from the Hikosan Biological Laboratory, Faculty of Agriculture, Kyushu
} University, Hikosan (Ser. 2, No. 47). 
irregularly carved ; prosternal process wide tongue-shaped, a little widened apically, apex widely rounded, with U-shaped deep groove, gently convex between coxal cavities.

Elytra much wider than pronotum, gradually widened posteriorly towards $3 / 5$ from base ; gently convex, strongly punctate-striate, interstices convex, finely, sparsely punctate; side margin narrowly marginate. Mesosternum with sparse, golden short pubescence, very roughly carved; V-shaped hollow very wide, shallow, roughly carved, basal half roughly rasped except for median line. Metasternum with hairs as well as mesosternum, with transversal wrinkles at median $1 / 3$; apical $1 / 3$ of median line deeply grooved. Visible abdominal sternites sparsely punctate, punctures gradually being sparser and finer from base to apex; side margin of 1 st to basal $3 / 4$ of 3 rd sternites narrowly marginate, apical $1 / 4$ of 3 rd to apical sternites not marginate.

Every femur comparatively thick ; inside without hairs; outwardly and medianly dilated, especially strongly dilated in front one, middle and hind ones gently compressed. Basal $2 / 3$ of front tibia gradually thickened towards apex, very gently bent inwards, apical $1 / 3$ extremely, strongly bent in- and downwards, inside of it scooped; apical $1 / 5$ densely pubescent except for outside, especially dense at apex; middle tibia slightly thickened towards apex, basal $3 / 4$ very feebly and apical $1 / 4$ comparatively, strongly bent inwards; hind tibia very slightly thickened towards apex, inside of $7 / 12$ from base dully

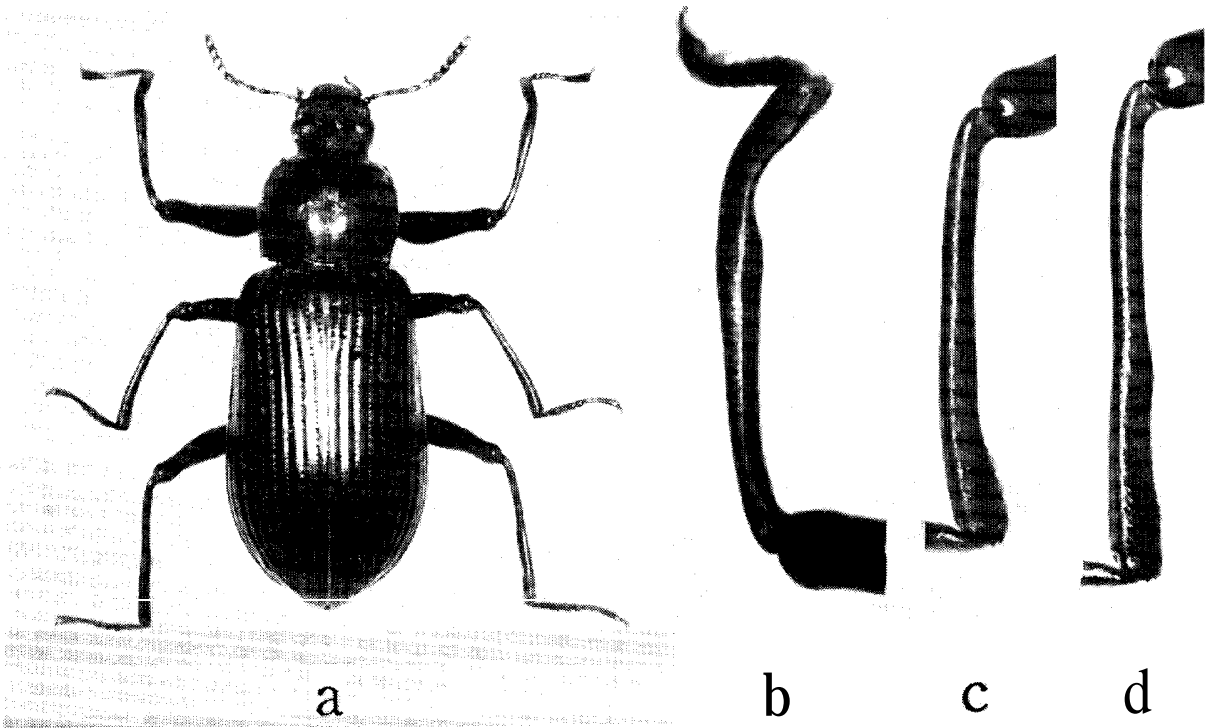

Fig. 1. Setenis aritai sp. nov. a: Type specimen (male in dorsal aspect). b: Front tibia. c: Middle tibia. d : Hind tibia. 
angulate, apical $1 / 3$ except for outside densely pubescent. Tarsi with dense, brushy hairs on undersurface ; apical segment of hind tarsus slightly shorter than the rest $(23: 27)$.

Female. Mentum strongly convex, densely, finely carved, sparsely pubescent. Pronotum strongly transverse (6.5:9.0). Front tibia gradually thickened towards apex, basal $3 / 5$ nearly straight, apical $2 / 5$ weakly, roundly bent inand downwards; middle tibia slightly compressed, basal $3 / 5$ nearly straight, apical $2 / 5$ very feebly bent in- and upwards; hind tibia with basal half nearly straight, apical half faintly bent inwards. Tarsi with fine, sparse hairs on undersurface ; apical segment of hind tarsus shorter than the rest $(5: 6)$.

Length : 17.4-23.8 mm. Width : 6.3-8.8 mm.

Distribution: Formosa.

Type material: Holotype $\precsim$ (Type No. 2321, Kyushu Univ.), Lienhuachih, Nantou Hsien, Formosa, 5. iii. 1968, Y. Arita leg. Paratopotypes: 3 ð \& 우, same data as holotype; $\precsim \&$ 우, 5. iii. 1968, T. Kunou leg. Paratypes : $q$ (B. P. Bishop Mus.), Rokki 300 m, Taiwan (SW), 17. v. 1934, J. L. Gressitt leg. ;ㅇ(B. P. Bishop Mus.), Puli (Hori), Taiwan (Formosa), vii. 1953, Native Collector leg. ; $4 \Varangle \nexists \&$ (B. P. Bishop Mus.), Puli (Hori), Taiwan, v. 1954, Native Collector leg. ; $283 \&$ 우 (B. P. Bishop Mus.), Hori, Formosa, vi. 1954, Native Collector leg. ; 자 \& 우 (B. P. Bishop Mus.), Puli (Hori), Taiwan (Formosa), vii. 1954, Native Collector leg. ; $ð$, Rishan, Formosa, 21-23. vii. 1968, Coll. H. Makihara ;

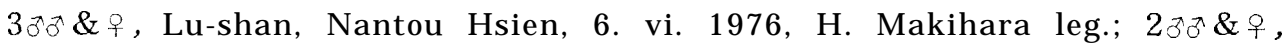
Lu-shan, Nantou Hsien, 20. vi. 1976, H. Makihara leg.

This species is closely related to S. setulosa Gebien, 1918, from Nias I., Indonesia, but is clearly distinguished from the latter by the following characters :

\section{S. setulosa Gebien}

Pronotal side margin deflex, hind corner obtuse, median groove entire from base to apex. In $ठ$ front tibia with sharply angulate projection at middle part of inside, hind tibia without remarkable character.

\section{S. aritai sp. nov.}

Pronotal side margin reflex, hind corner rather acute, median groove disappearing for- and backwards. In $\sigma^{\star}$ front tibia gradually thickened towards $2 / 3$ from base, inside of apical $1 / 3$ scooped, inside of hind tibia slightly expanded at $7 / 12$ from base.

\section{Setenis nitidula sp. nov.}

Setenis striatipennis: M. T. Chûjô, 1967 (nec Lewis, 1894), Kontyû 35(4) : 378.

Male. Elongate, moderately convex, shining black.

Head somewhat transverse, feebly convex, sparsely, strongly punctate; with clypeal suture semicircular, clypeus gently, roundly bent downwards, 
front margin very shallowly sinuate; preocular area moderately convex, side margin very slightly, roundly expanded outwards; inner ocular groove very shallow, not extending backwards ; inner ocular furrow very feebly convex; interocular area about 1.6 times as wide as eye. Eye gently, roundly expanded outwards, slightly longitudinal.

Antenna rather moniliform, apical 6 segments forming a little compressed loose club; relative length of each segment (base to apex), $7: 3: 7: 6: 6: 6$ : $6: 5: 5: 4: 7$. Maxillary palpus rather securiformed. Mentum wholly covered with dense, long, erect, brown hairs. Gular suture distinct, very strongly, roughly carved from tempora to gula.

Pronotum transverse (3:4), evenly, gently, roundly convex, sparsely, strongly punctate, very narrowly marginate except for middle part of front margin; subbasal grooves very shallow and oblique; front margin widely, shallowly sinuate, front corner rounded, slightly prominent forwards ; anterior $7 / 9$ of side margin strongly, roundly expanded outwards, basal 2/9 very shallowly sinuate ; hind corner acutely pointed, nearly rectangular; basal margin trisinuate, middle sinus very narrow and shallow. Propleuron strongly convex, sparsely punctate. Prosternum wholly, roughly punctate and carved ; apical half of median part transversely wrinkled; prosternal process roundly convex between coxal cavities, side margin widely marginate, strongly reflex along coxal cavity.

Elytra comparatively strongly convex, nearly parallel-sided ; punctatestriate, interstices very weakly convex, densely, finely punctate; side margin narrowly marginate from shoulder to apex, shoulder obliquely truncate. Mesosternum with front half strongly rasped except for median line, with sparse, fine, long pubescence, basal half strongly convex; V-shaped depression wide, very shallow. Metasternum without dense pilosity in middle part, sparsely, uniformly pubescent; strongly, roundly convex ; very sparsely punctate, irregularly wrinkled.

First, 2nd and basal $2 / 3$ of 3rd visible abdominal sternites marginate; 1 st sternite with shallow depression in middle part, with dense punctures and rather longitudinal wrinkles. Every femur somewhat slender; middle and hind femora weakly compressed. Front tibia with basal $3 / 5$ nearly straight; apical $2 / 5$ thickened towards apex, strongly, roundly bent in- and downwards ; inside of apical $1 / 5$ very densely pubescent. Middle tibia with basal $5 / 8$ of outside nearly straight, inside of apical $5 / 8$ shallowly sinuate, apical $1 / 3$ strongly thickened towards apex, gently bent in- and upwards, Hind tibia with apical $1 / 3$ strongly thickened towards apex, very weakly bent in- and upwards; basal $2 / 3$ of outside nearly straight; inside bisinuate and gently angulate at $1 / 3$ from base; inside of apical $1 / 3$ densely pubescent. Every tarsus somewhat short; relative length of each segment (base to apex), front one $5: 3: 2: 3$ : 15 , middle one $12: 3: 3: 4: 18$, and hind one $14: 5: 5: 19$. 


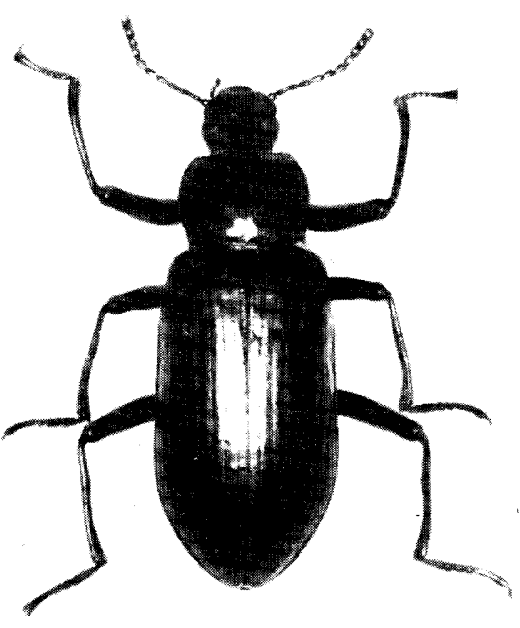

a

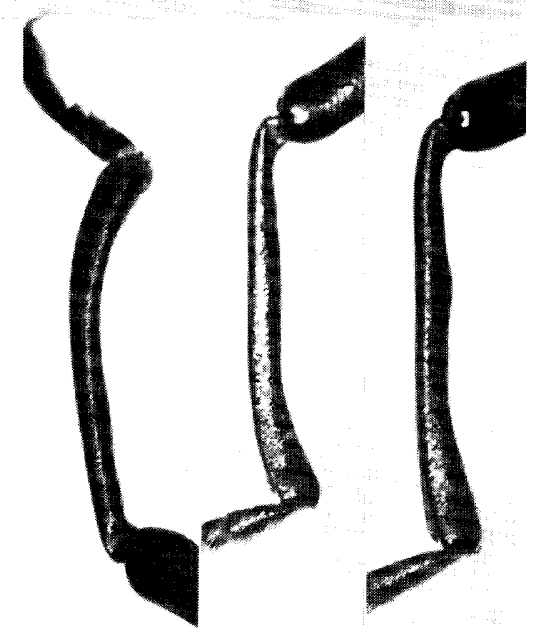

b c

C d

Fig. 2. Setenis nitidula sp. nov. a : Type specimen (male in dorsal aspect). b : Front tibia, c: Middle tibia. d: Hind tibia,

Female. Interocular area twice as wide as eye; relative length of antennal segments (base to apex), $7: 3: 6: 5: 5: 5: 5: 4: 4: 4: 8$. Mentum with very sparse brown pubescence. Apical $2 / 5$ of front tibia weakly, roundly bent in- and upwards ; middle tibia with apical $3 / 10$ very weakly bent in- and upwards; hind tibia very slender, basal $2 / 3$ nearly straight; apical $1 / 3$ gradually thickened towards apex, weakly, roundly bent in- and upwards.

Length : 19.0-22.8 $\mathrm{mm}$. Width : 7.2-8.4 $\mathrm{mm}$.

Distribution: Formosa.

Type material: Holotype $\precsim$ (Type No. 2322, Kyushu Univ.), Sungkang, Nantou Hsien, Taiwan, 31. v. 1965, T. Shirôzu leg. Paratypes: ơ (B. P. Bishop Mus.), Taiheizan, Formosa, 7. v. 1932, J. L. Gressitt leg. ;우, Sungkang, Nantou Hsien, Formosa, 24. vi. 1965, T. Shirôzu leg. ;우, Juiyen, Nantou Hsien, Formosa, 17. vii. 1966, B. S. Cheng leg.

This species is closely related to S. striatipennis Lewis, 1894 from Japan, but is clearly distinguished from the latter by the following characters:

\section{S. striatipennis Lewis}

Preocular area to clypeus semicircular; pronotum with median groove; in o front tibia evenly, roundly bent inand downwards; hind tibia very feebly arcuate.
$\mathrm{S}$. nitidula sp. $\mathrm{nov}$.

Preocular area to clypeus nearly trapezoidal; pronotum without median

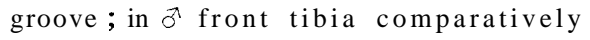
strongly bent in- and downwards; hind tibia with $1 / 3$ from base of inside dully angulate. 


\section{Setenis similis sp. nov.}

Male. Elongate, moderately convex, glossy black.

Head nearly flat, strongly, sparsely punctate, especially sparser at interocular area; preocular area weakly convex, not expanded, slightly intrudes into eye; clypeal suture very fine, semicircular, front margin gently bent downwards, very shallowly sinuate ; inner ocular groove narrow and shallow, inner ocular furrow feebly convex. Eye very strongly prominent outwards, finely facetted.

Antenna very slender, 1st segment thick, 3rd segment most slender, weakly bent backwards, apical 6 segments forming loose club, 7th to terminal segments gradually flattened; relative length of each segment (base to apex), $7: 3: 9: 7: 6: 6: 6: 5: 5: 5: 6$. Maxillary palpus moderately securiformed, apex weakly rounded. Mentum with dense, thick, erect, long brown hairs. Gular suture visible, very strongly carved from tempora to gula.

Pronotum transverse (3:4), moderately convex, sparsely, strongly punctate, subbasally with short, oblique, shallow groove; wholly, very narrowly mar. ginate except for middle $1 / Z$ of front margin, front margin evenly, very shallowly sinuate, front corner widely rounded; side margin gently, roundly expanded; hind corner nearly rectangular, hind margin shallowly bisinuate. Propleuron very sparsely, finely punctate. Prosternum sparsely, strongly punctate; prosternal process with U-shaped shallow groove, median part roughly carved, depressed, marginal part strongly reflex along coxal cavity.

Elytra moderately convex, weakly widened posteriorly to about $3 / 5$ from base, apex rounded ; side margin wholly, narrowly marginate ; strongly punctatestriate, interstices strongly convex, sparsely, finely punctate ; every puncture with a very fine, short hair. Epipleuron with a row of very sparse golden pubescence along inner margin at basal half. Mesosternum weakly rasped in front half except for median line, with very wide, extremely shallow, V. shaped depression in basal half. Metasternum convex, weakly depressed around median suture ; very sparsely, shallowly punctate, irregularly wrinkled along basal margin; with very sparse, fine, comparatively long pubescence.

Visible abdominal sternites densely punctate, punctures being sparser and finer from base to apex in every sternite; 1st sternite weakly depressed at middle part, side margin of 1 st to basal $3 / 4$ of 3 rd sternites narrowly marginate. Front femur comparatively thick, inside nearly straight, outside dilated, thickest at 5/12 from base; middle and hind femora slightly compressed. Front tibia with $7 / 12$ from base nearly straight, cylindrical ; apical 5/12 gradually thickened towards apex, strongly, roundly bent in- and downwards, underside very weakly scooped; apical $1 / 6$ very densely pubescent except for outside. Middle tibia slightly compressed, gently thickened towards apex; basal $2 / 3$ nearly straight, apical $1 / 3$ weakly bent in and upwards. Hind tibia slightly 


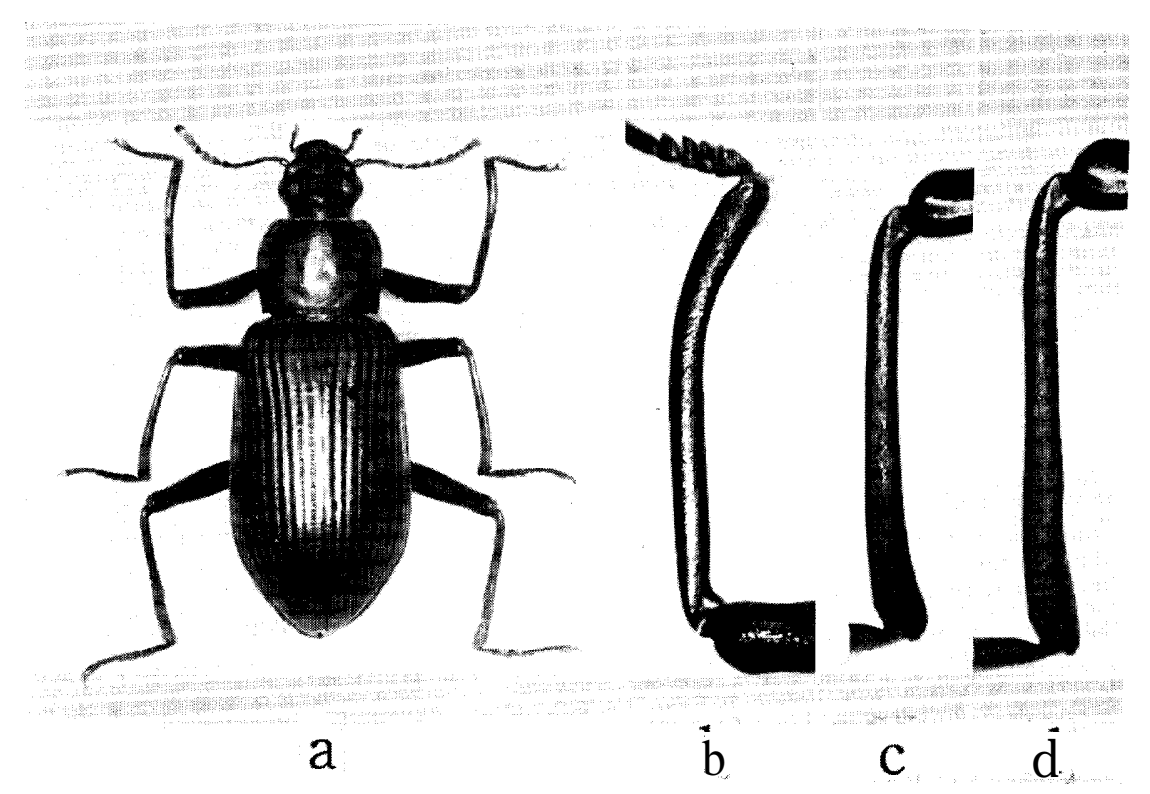

Fig. 3. Setenis similis sp. nov. a: Type specimen (male in dorsal aspect). b: Front tibia. c: Middle tibia. d: Hind tibia.

compressed, gradually thickened towards apex; apical $3 / 8$ of inside very shallowly sinuate and densely pubescent, apical $1 / 4$ very feebly bent in- and upwards. Relative length of each tarsal segment (base to apex), front one $6: 3: 3: 4: 8$, middle one $12: 5: 4: 5: 21$, and hind one $15: 6: 5: 22$.

Female. Unknown.

Length : $19.5 \mathrm{~mm}$. Width : $8.0 \mathrm{~mm}$.

Distribution : Formosa.

Type material : Holotype $\sigma^{\pi}$ (Type No. 2323, Kyushu Univ.), Lu-shan, Nantou Hsien, Formosa, 6. vi. 1976, H. Makihara leg,

This species is closely related to S. okinawana M. T. Chîjô, 1978 from Okinawa-Honto Island, but is clearly distinguished from the latter by the following characters :

\section{S. okinawana M. T. Chûjjô}

Generally larger in size, eye gently expanded outwards, 3rd antennal segment 2.25 times as long as 2 nd. Pronotal side margin strongly expanded, hind corner forming an angle of ca. 80 degrees. Elytral punctate-striae shallow, interstices weakly convex.

\section{S. similis sp. nov.}

Generally smaller in size, eye very strongly expanded outwards, 3rd antennal segment 3 times as long as 2nd. Pronotal side margin gently expanded, hind corner nearly rectangular. Elytral punctate-striae deep, interstices strongly convex. 


\section{Setenis subvalgipes sp. nov.}

Male. Elongate, rather strongly convex, shining black.

Head rather transverse, not convex, sparsely, strongly, evenly punctate ; front margin roundly bent downwards, shallowly sinuate at apex, free of puncture along vestigial clypeal suture; preocular area convex, not expanded, rather parallel-sided at basal half and then strongly bent forwards; inner ocular groove very shallow, not expanding backwards, inner ocular furrow very feebly convex. Eye rather transverse, gently, roundly expanded outwards.

Antenna with apical half dark brown, somewhat slender, apical 6 segments forming loose club, 7th to apical segments gradually strongly flattened, relative length of each segment (base to apex), $7: 4: 10: 8: 7: 6: 7: 6: 5:$ 5 : 9. Maxillary palpus comparatively strongly securiformed. Mentum roughly carved, wih very sparse, short pubescence. Gular suture distinct, very strongly, roughly carved from tempora to gula.

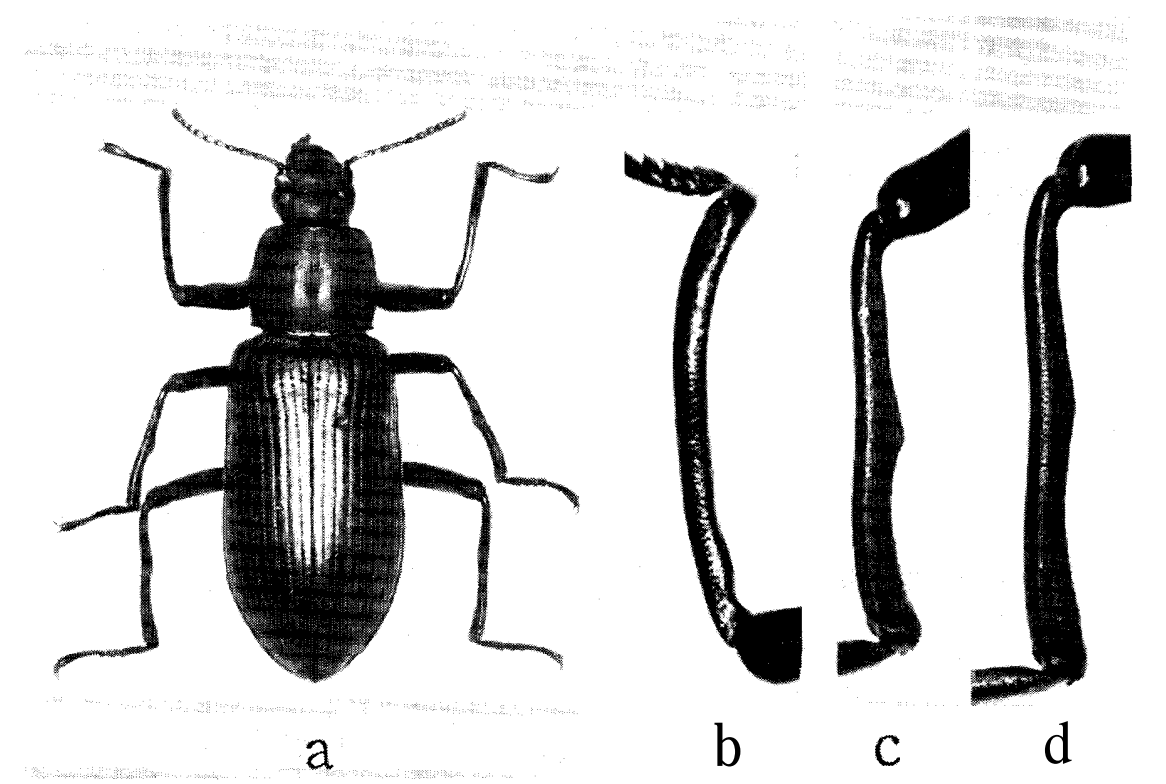

Fig. 4. Setenis subvalgipes sp. nov. a: Type specimen (male in dorsal aspect). b: Front tibia. c: Middle tibia. d: Hind tibia.

Pronotum rather transverse (5:6), weakly convex, wholly, narrowly marginate, densely, strongly punctate, median groove complete, subbasal grooves indistinct; front margin truncate, front corner widely rounded; side margin very feebly, roundly widened backwards, widest at $5 / 8$ from apex, basal $3 / 8$ very feebly, shallowly sinuate and narrowed; hind corner somewhat 
rectangular, pointed, hind margin gradually, roundly expanded backwards. Propleuron strongly wrinkled. Prosternum with marginal area densely carved, middle part sparsely punctate ; prosternal process widely marginate, roundly convex between coxal cavities, apical margin strongly reflex, median part very densely, strongly carved.

Elytra comparatively strongly convex, very gently widened posteriorly to about 4/7 from base, thence roundly narrowed towards apex: strongly punctatestriate, interstices gently convex, sparsely, finely punctate; side margin from shoulder to apex very narrowly marginate, marginal area of base gently raised, shoulder obliquely truncate. Mesosternum with dense, fine, long yellow pubescence ; strongly rasped in front half except for median line; with wide, deep V-shaped depression in basal half, surface of depression roughly carved, with very sparse, short pubescence. Metasternum with fine pile, strongly punctate, apical half wrinkled; median groove comparatively deep.

Visible abdominal sternites very densely punctate, wrinkled, 1 st to $3 / 5$ of 3rd segments finely marginate at side. Every femur simple. Front tibia with basal $2 / 3$ gently, apical $1 / 3$ rather strongly bent in- and downwards ; apical $1 / 5$ very slightly thickened, pubescent. Middle tibia compressed, biarcuate, middle part of inside strongly angulate, inside of apical $1 / 2$ with sparse, short pubescence. Hind tibia compressed, biarcuate ; inside of $6 / 13$ from base dully angulate, apical half gently reflex. Relative length of each tarsal segment (base to apex), front one $10: 4: 4: 5: 30$, middle one $16: 6: 5: 6: 32$, and hind one $22: 7: 7: 44$.

Female. Mentum with sparse, fine, brown pubescence. Metasternum with very sparse, fine, yellow pubescence, very shallowly depressed around median suture. Front tibia very weakly thickened towards apex, apical 1/3 gently, roundly bent in- and downwards; middle one compressed, nearly straight, gradually thickened towards apex, apical half gently reflex; hind one compressed, with basal half nearly straight, apical half reflex, weakly, roundly curved outwards. Relative length of each tarsal segment (base to apex), front one $10: 5: 5: 7: 37$, middle one $10: 5: 5: 27$, and hind one $15: 5: 6: 27$.

Length : 23.2-23.8 mm. Width :8.2-8. $3 \mathrm{~mm}$.

Distribution : Formosa.

Type material: Holotype ${ }^{\curvearrowright}$ (Type No. 2324, Kyushu Univ.), Nanshanchi, Nantou Hsien, Formosa, 23. vii. 1968, K. Yamamoto leg. Paratypes : 2 우우, Kenting Park, Formosa, 3. viii. 1970, Coll. M. Chûjô.

This species is closely related to S. valgipes Marseul, 1876 from Japan, but is clearly distinguished from the latter by the following characters: 


\section{S. valgipes Marseul}

Generally much larger in size, punctures on head and pronotum much sparser, elytral interstices not convex, nearly smooth, metasternal depression in $\delta$ distinct.
S. subvalgipes $\mathrm{sp}$. nov.

Generally much smaller in size, punctures on head and pronotum much denser, elytral interstices gently convex, sparsely punctate, metasternal depression in $\vec{\sigma}$ indistinct.

The males of the four new species of Formosan Setenis described in this paper are separated by the following key.

1: Front tibia with apical 1'3 extremely strongly bent in- and downwards, inside of crooked part scooped aritai

1': Front tibia with apical $1 / 3$ strongly bent in- and downwards, inside of crooked part not scooped.....

2 : Inside of hind tibia without angulate part, metasternum without dense

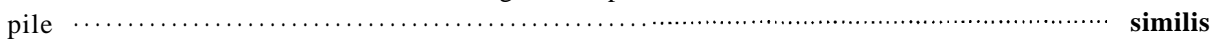

2': Inside of hind tibia with somewhat angulate part, metasternum with dense

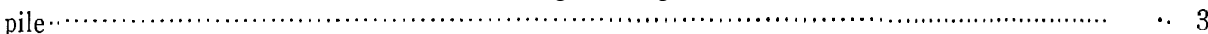

3 : Dull black, pronotum with median groove, inside of middle tibia strongly angulate in middle part, apical $1 / 3$ gently bent in- and upwards …........ subvalgipes

${ }^{3 \prime}$ : Shining black, pronotum without median groove, basal $3 / 5$ of middle tibia nearly straight, apical $2 / 5$ widened towards apex, strongly bent in- and upwards

nitidula

\section{Acknowledgements}

I wish to express my appreciation to Prof. Y. Hirashima, the head of Hikosan Biological Laboratory, for making this study possible and for his kind guidance in the preparation of the manuscript. Also, I express my cordial thanks to Prof. Emeritus K. Yasumatsu, Prof. Emeritus T. Shirôzu and Assoc. Prof. K. Morimoto of Kyushu University, and also, Mr. T. Shibata of Osaka City for their continual, kind and valuable advice. I wish to express my cordial thanks to Dr. J. L. Gressitt and the authorities of Bernice P. Bishop Museum, U. S. A., who kindly permitted me of examining their valuable specimens. My sincere thanks are due to Prof. M. Sato of Nagoya Women's University, Mr. Y. Arita of Meijô University, Mr. H. Makihara of Forestry and Forest Products Research Institute who kindly gave me so many valuable specimens. Particular thanks are due to Prof. Emeritus M. Chûjô of Kagawa University for his help to my study. 